ISSN 2078-6441. Вісник Львівського університету. Серія географічна. 2014. Випуск 47. С. 164-170. Visnyk of the Lviv University. Series Geography. 2014. Issue 47. P. 164-170.

[504.453:332.4](477.83)

\author{
юдмил ург невич, ілі н ербенець \\ ввівський н ціон льний університет імені в н \\ вул. . орошенк , 41, 79000, м. ввів, кр їн
}

\begin{abstract}
бгрунтов но кту льність дослідження геоекологічного ст ну річкових систем ун слідок н лізу нтропогенного н в нт ження н їхні 6 сейни. озглянуто основні підходи до оцінки рівня нтропогенного н в нт ження н річково-б сейнову систему; про н лізов но структуру землекористув ння, оцінено ступінь екологічної стійкості л ндш фтів, екологічної зб л нсов ності території, екологічного н пруження в меж х 6 сейну р. т .

лючові слов : річково-б сейнов систем, нтропогенне н в нт ження, землекористув ння, екологічн стійкість.
\end{abstract}

нтегр ційний європейський поступ кр їни зобов'язує ретельніше ст витись до якості довкілля як основи екологічної безпеки держ ви. собливо це стосується тр нскордонних територій, i, зокрем , т ких, як річково-б сейнов систем хідного угу, як $є$ спільною л нкою екологічних інтересів кр їни, ілорусі й ольщі т перебув є в полі зору н уковців.

колого-геоморфологічні дослідження верхньої ч стини б сейну хідного угу проводили . ов льчук, . ург невич (2001), н ліз гідроекологічного ст ну 6 сейну хідного угу н території кр їни викон ли . бокрицьк , · ільчевський, нченко (2006), екологічний ст н укр їнської ч стини врорегіону “ уг” визн чили . лименко, . ознюк (2007), з ходи з оптиміз ції природокористув ння в 6 сейні ріки хідний уг у меж х олинської обл. з пропонов но . оярин (2011) тощо.

еоекологічн ситу ція в б сейні ріки хідний уг визн чен якістю компонентів довкілля т їхньою стійкістю до нтропогенних н в нт жень н рівні 6 сейнів м лих річок основних приток. ому геоекологічні дослідження в меж х субб сейнів (ріки

т , олтв , олокія) верхньої ч стини $б$ сейну хідного угу є досить кту льними, про що свідчить низк публік цій ост нніх років [3-8].

йбільшою лівою притокою хідного угу в меж $\mathrm{x} \quad$ кр їни $є$ річк $\quad$ т - об'єкт н ших досліджень. жливим пок зником, що визн ч є геоекологічний ст н річково6 сейнової системи, є рівень нтропогенного н в нт ження т його вплив н стійкість природних л ндш фтів. ому н ш мет - оцінк стійкості геокомплексів б сейну річки т вн слідок н лізу рівня нтропогенного н в нТ ження т визн чення ступеня тр нсформ ції природного потенці лу довкілля.

еоретико-методичні т прикл дні спекти визн чення рівня нтропогенного н в нт ження н геосистеми н лізув ли . ищенко (1988), . p новський (2001), . рик (2006), . е ер симів (2008) т ін. [1, 2, 9-11]. різними методичними підход ми ми розр хув ли коефіцієнт екологічної стійкості л ндш фтів, коефіцієнт нтропогенної

(C) ург невич ., ербенець ., 2014 
тр нсформ ції території, ступінь стійкості земельних угідь, рівень екологічного н пруження в меж х річково-б сейнової системи ти т ін.

ічково-б сейнов систем ти розміщен в меж х тинської денуд ційнокумулятивної рівнини лого олісся т вододільних розчленов них горбистих денуд ційно-структурних височин озточчя - вського і ьвівського. бсолютні висоти у виток х річок ст новлять 250-380 м, в нижній течії - до 200-250 м. охили водотоків пон д 2 м/км (ріки іл, ощ нк, еревеньк), від 1 до 2 (ріки виня, елдець) т до 1 м/км (р. олотня). г льн довжин річки - 75 км, площ 6 сейну $1820 \mathrm{kM}^{2}$ (т бл. 1).

ідрогр фічні х р ктеристики річки $\quad$ т т

\begin{tabular}{|c|c|c|c|c|c|c|}
\hline ічк & уди в п д $\mathbf{\epsilon}$ & $\begin{array}{c}\text { овжин , } \\
\text { км }\end{array}$ & $\begin{array}{c}\text { лощ } \\
\text { водозбору, } \\
\text { км }^{2}\end{array}$ & $\begin{array}{c}\text { ирин } \\
\text { русл , м }\end{array}$ & $\begin{array}{c}\text { ирин } \\
3 \text { пл ви, м }\end{array}$ & $\begin{array}{c}\text { охил, } \\
\text { м/к м }\end{array}$ \\
\hline $\mathrm{T}$ & хідний $\quad$ уг & $75 / 68$ & $1820 / 1770$ & $5-20$ & 1000 & 1,2 \\
\hline елдець & $\mathrm{T}$ & 43 & 249 & $7-12$ & 400 & 1,1 \\
\hline виня & $\mathrm{T}$ & 44 & 515 & $5-10$ & 500 & 1,5 \\
\hline іл & $\mathrm{T}$ & 40 & 180 & $3-6$ & 800 & 3,0 \\
\hline ОЩ HK & $\mathrm{T}$ & 36 & 190 & $3-6$ & 500 & 3,6 \\
\hline олотня & $\mathrm{T}$ & 34 & 252 & $5-7$ & 300 & 0,7 \\
\hline еревеньк & $\mathrm{T}$ & 36 & 150 & $5-7$ & 700 & 2,5 \\
\hline
\end{tabular}

ьогодні в р йоні досліджень функціонує три гідрологічні пости. них щоденно вимірюють витр ти води (р. т, с. ежиріччя; p. т, с. олиця, р. виня, м. овкв ), і лише н одному - витр ти з вислих н носів (p. т, с. олиця). постереження 3 хімічним скл дом природних вод розпоч ли в системі гідрометеослужби з 1936 р. 1974 р. ведуть спостереження з якістю поверхневих вод.

ередньоб г торічний модуль стоку р. т - 4,9 л/с км² (т бл. 2). 6 г торічному спекті чітко виділяється циклічність колив нь водності р. $\quad$ т $\quad$ т їі основних приток чергув ння б г то- і м ловодних періодів, деяке підвищення т пл вне зниження водності.

блиця 2

г торічні х р ктеристики середньорічного стоку води річки т

\begin{tabular}{|c|c|c|c|c|}
\hline ідропост & $\begin{array}{c}\text { итр т в води, } \\
\mathrm{M}^{3} / \mathrm{c}\end{array}$ & б'єм стоку, млн м & $\begin{array}{c}\text { одуль стоку, } \\
\text { л/с к м }\end{array}$ & р стоку, мм \\
\hline ежиріччя & 8,05 & 246 & 4,6 & 145 \\
\hline олиця & 6,02 & 190 & 5,3 & 167 \\
\hline
\end{tabular}

сейн річки т з зн є різном нітного господ рського впливу, зокрем, це зн чне водокористув ння, сільськогоспод рське природокористув ння, інтенсивн осушув льн меліор ція, високе поселенське освоєння, тр нспортне т промислове н в нт ження, що відобр ж ється н гідроекологічній ситу ції досліджув ного регіону. підст ві н лізу якості води в річці т ст ном н 2012 р. з зн чимо, що перевищення простежено 3 монієм сольовим у першому т другому кв рт л $\mathrm{x}, 5$ другому-четвертому кв рт л х, з нітрит ми і $\mathrm{Fe}$ - протягом року (див. т бл. 3 ). 

ISSN 2078-6441. Вісник Львівського університету. Серія географічна. 2014. Випуск 47

блиця 3

імічний скл д т якість води р. т , м. еликі ости, 2012 [13]

\begin{tabular}{|c|c|c|c|c|c|}
\hline \multirow{2}{*}{ ок ЗНИКИ } & \multicolumn{4}{|c|}{ B p T $\pi$} & \\
\hline & & & & IV & \\
\hline розорість & 18,00 & 30,00 & 19,00 & 22,00 & \\
\hline емпер тур,${ }^{\circ} \mathrm{C}$ & 8,00 & 11,00 & 15,00 & 13,00 & \\
\hline вислі речовини, мг/дм ${ }^{3}$ & 9,00 & & 25,00 & 12,00 & \\
\hline $\mathrm{HCO}_{3}$, мг/дм ${ }^{3}$ & 268,40 & 390,40 & 292,80 & 268,40 & \\
\hline лій т н трій, мг/дм ${ }^{3}$ & 32,17 & 8,10 & 6,40 & 32,50 & 170,00 \\
\hline льцій, мг/дм ${ }^{3}$ & 66,10 & 104,20 & 102,20 & 88,20 & 180,00 \\
\hline гній, мг/дм ${ }^{3}$ & 7,30 & 24,30 & 10,90 & 8,50 & 40,00 \\
\hline ульф ти, мг/дм ${ }^{3}$ & 32,60 & 28,40 & 37,10 & 53,60 & 100,00 \\
\hline ухий з лишок & 300,00 & 396,00 & 340,00 & 360,00 & 1000,00 \\
\hline лориди, мг/дм ${ }^{3}$ & 10,60 & 19,50 & 25,50 & 34,00 & 300,00 \\
\hline $\mathrm{pH}$ & 7,50 & 7,90 & 7,50 & 7,80 & 8,50 \\
\hline моній сольовий, мг/дм ${ }^{3}$ & 1,20 & 0,58 & 0,13 & 0,30 & 0,50 \\
\hline 5, мг/дм ${ }^{3}$ & 1,40 & 2,40 & 2,90 & 2,70 & 2,26 \\
\hline вердість & 3,90 & 7,20 & 6,00 & 5,10 & \\
\hline ужність & 4,40 & 6,40 & 4,80 & 4,40 & \\
\hline ітр ти, мг/дм ${ }^{3}$ & 0,63 & 5,50 & 1,50 & 4,00 & 40,00 \\
\hline ітрити, мг/дм ${ }^{3}$ & 0,10 & 0,12 & 0,10 & 0,20 & 0,08 \\
\hline /кисень, мг/дм ${ }^{3}$ & 8,08 & 8,40 & 9,10 & 5,20 & \\
\hline осф т-іони, мг/дм ${ }^{3}$ & 0,10 & 0,13 & 0,05 & 0,14 & 0,17 \\
\hline, $\mathrm{мг} /$ дм $^{3}$ & 13,20 & 12,60 & 13,00 & 12,90 & 15,00 \\
\hline $\mathrm{Fe}$, мг/дм ${ }^{3}$ & 0,70 & 0,65 & 0,60 & 0,27 & 0,10 \\
\hline
\end{tabular}

цінку нтропогенного впливу н річково-б сейнову систему ти зроблено н підст ві комплексу пок зників, які відобр ж ють структуру землекористув ння досліджув ної території (див. рисунок).

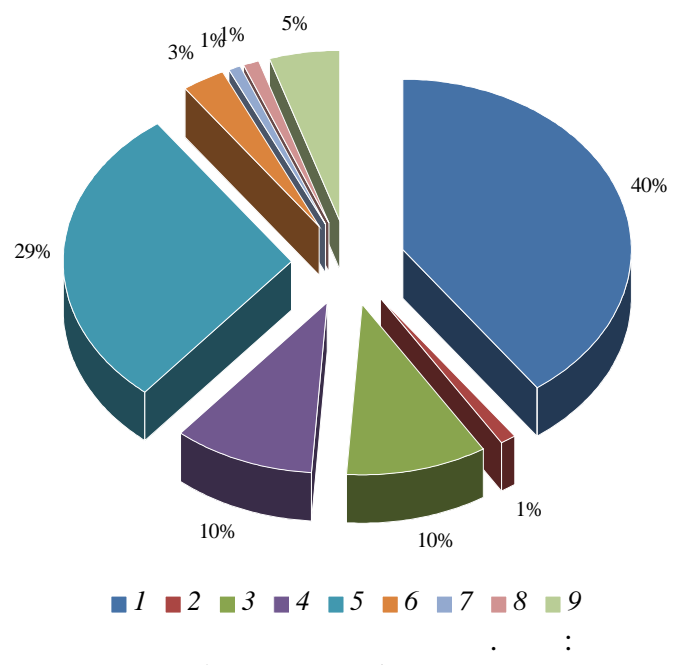

1 - рілля; 2 - 6 г торічні н с дження; 3 - сінож ті; 4 - п совищ ; 5 -ліси т інші лісовкриті площі; 6 - з будов ні землі; 7 - болот ; 8 - відкриті землі без рослинного покриву; 9 - внутрішні води 
ередня сільськогоспод рськ освоєність території б сейну ст новить пон д $60 \%$.

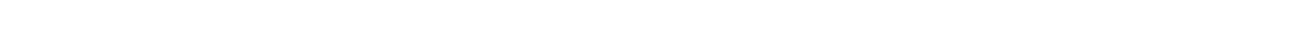
добр (т бл. 4). енш освоєні й більш з ліснені привододільні ділянки річкового 6 сейну. ередня з лісненість б сейну річки ст новить $29 \%$, що визн ч є з г льний ступінь $з$ ліснення як добрий (пон д 20\%). структурі земель н території 6 сейну p. т перев ж є рілля. ередня розор ність - близько $40 \%$ і цей пок зник ув ж ють добрим. йнижч розор ність з фіксов н в меж $\mathrm{x}$ дміністр тивних одиниць з високою з лісненістю т зн чною розчленов ністю рельєфу.

стк сінож тей $i$ n совищ у структурі сільськогоспод рських угідь ст новить $20 \%$. йвищим цей пок зник $є$ н територіях з порівняно невеликою ч сткою земель, прид тних для розорюв ння. ередня урб нізов ність у б сейні річки ст новить до $3 \%$, іiі x р ктеризують як поліпшену. йменшу площу з йм ють 6 г торічні н с дження, відкриті з болочені землі і відкриті землі без рослинного покриву (1\%).

р зі оцінюв ння ступеня екологічної стійкості л ндш фтів, екологічної зб л нсов ності території, стійкості грол ндш фтів, екологічного н пруження в меж х річково-б сейнової системи ти основними розр хунковими одиницями обр но сільські т селищні р ди овківського, ок льського, м'янк - узького і ворівського р йонів ьвівської обл., які є н території досліджень (усього 45 дміністр тивних утворень).

лов цькі вчені. лементов і . ейнеге у ході визн чення коефіцієнт екологічної стійкості л ндш фту ( ) з пропонув ли в меж х території досліджень виділяти ст більні т нест більні елементи л ндш фту. т більні, н думку вторів, це елементи, які позитивно вплив ють н л ндш фт. о них н леж ть території, з йняті під ліс ми, лісосмуг ми, болот ми т з болоченими землями, лук ми, п совищ ми, природоохоронними територіями, фруктовими с д ми і виногр дник ми. о нест більних елементів н леж ть сільські і міські з будови, рілля, городи, водосховищ , водотоки, К н ли і землі промислового використ ння. оефіцієнт екологічної стійкості л ндш фту розр ховують як відношення площ ст більних елементів л ндш фту до нест більних.

лежно від отрим них зн чень викон но оцінку стійкості л ндш фту з т кою кл сифік цією: $\leq 0,5$ - нест більн з яскр во вир женою нест більністю; $0,5<\leq 1,0-$ нест більн ; $1,0<\leq 3,0-$ умовно ст більн ; $3,0<\quad \leq 4,5-$ ст більн ; > 4,5-ст більн з яскр во вир женою ст більністю.

к $з$ свідчили н ші дослідження, у меж х б сейну р. т нем територій зі ст більною екологічною стійкістю л ндш фтів. о $62 \%$ сейну з йм ють території з нест більною і нест більною з яскр во вир женою нест більністю екологічною стійкістю л ндш фтів, решт території - умовно ст більні. г лом екологічн стійкість л ндш фтів території досліджень - нест більн .

оефіцієнт екологічної стійкості л ндш фтів корелює з ч сткою нтропогенних геосистем, ступенем природного вигляду території, коефіцієнтом нтропогенного н в нт ження, ступенем стійкості земельних угідь т іншими інтегр льними пок зник ми. стку нтропогенних геосистем н певній території розр ховують як відношення суми площ, з йнятих ріллею т з будов ними землями, до з г льної площі.

тупінь природного вигляду території - це відношення площі угідь, що перебув ють у природному ст ні (боліт, водних територій, лісів природного і штучного походження, з хисних водоохоронних н с джень, з повідних територій), т кож угідь, близьких до нього (п совищ, сінож тей, покл дів), до з г льної площі $б$ сейну. г лом у б сейні ти ступінь природного зовнішнього вигляду ст новить $30 \%$, і цей пок зник є нез довільний (див. т бл. 4). 

ISSN 2078-6441. Вісник Львівського університету. Серія географічна. 2014. Випуск 47

блиця 4

л сифік ція використ ння земельних ресурсів у 6 сейн х м лих річок зони ісостепу (провінція ісостепов хідн ) [9]

\begin{tabular}{|c|c|c|c|c|c|}
\hline \multirow{2}{*}{ ок зники } & \multicolumn{5}{|c|}{ ритерії, \% } \\
\cline { 2 - 6 } & нез довільний & нижче норми & норм льний & покр щений & добрий \\
\hline ісистість & $<15$ & $15-17$ & 17 & $18-20$ & $>20$ \\
\hline тупінь природного & $<35$ & $35-40$ & 40 & $40-45$ & $>45$ \\
зовнішнього вигляду & & $75-70$ & 70 & $70-65$ & $<65$ \\
\hline ільгоспосвоєність & $>75$ & $60-55$ & 55 & $55-50$ & $<50$ \\
\hline озор ність & $>60$ & $5-4$ & $3-4$ & $3-2$ & $<2$ \\
\hline рб нізов ність & $>5$ & \multicolumn{4}{|c}{} \\
\hline
\end{tabular}

оефіцієнт нтропогенної тр нсформ цї̈ територї розр ховують як відношення площі земель під сільськогоспод рськими угіддями, з будовою і дорог ми до з г льної площі території. меж х території досліджень він є досить високим $(0,64)$, його зн чення колив ється від 0,27 ( ередкевичівськ сільськ р д ) до 0,93 ( мочківськ т мереківськ сільські р ди).

оефіцієнт екологічної зб л нсов ності території визн ч ють як відношення площі орних земель до площі лісових, лукоп совищних і водних угідь. середньому в б сейні цей пок зник ст новить 1,5.

оефіцієнт стійкості грол ндш фтів - це відношення суми площ умовно екологічно ст більних угідь (сінож тей, п совищ, лісів, боліт), т кож земель, відведених під ре біліт цію т регенер цію, до сум рної площі орних земель і б г торічних н с джень. середньому в б сейні ти коефіцієнт ст новить 1,6, що перевищуе нижню межу стійкості $(0,7)$. ише в меж х п'яти дміністр тивних одиниць цей пок зник досяг є нижньої межі стійкості.

гідно з дослідженнями . риб , лименк , . онд к (1999), для норм льного функціонув ння екосистеми допустиме співвідношення порушених т умовно порушених площ у іï меж х повинно ст новити 1:3. орушення $40 \%$ екологічних зв'язків веде до дегр д ції екосистеми. середньому ч стк нтропогенних геокомплексів у меж х досліджув ного б сейну ст новить 0,48. йвищ - н території елдецької сільської р ди, смт герів, оле- исоцької, еревнянської, улявської,

цошинської, овок м'янської, ідліської, ог риської, ернівської і мереківської сільських р д.

кож визн чено екологічне н в нт жеення в б сейні ти. інтегр льним пок зником суми б льних оцінок кожного дест білізув льного чинник, розр хов ного для кожного 3 дміністр тивно-територі льних утворень, екологічн ситу ція в б сейні нез довільн .

ля оцінки екологічного ризику, пов'яз ного зі ст ном земель, визн чено інтегр льний пок зник ст ну земель, який з лежить від бонітету грунтів, ч стки т продуктивності нтропогенно-природних геосистем, ч стки т продуктивності нтропогенних геосистем, т кож коефіцієнт, що вр ховує н явність відходів першого-третього кл су небезпеки н кінець звітного року у спеці льно відведених місцях чи об'єкт х.

ідповідно до обчислених пок зників ст ну земель можн викон ти оцінку ступеня екологічного ризику досліджув ної території. підст ві н лізу визн чених пок зників, з зн чимо, що з г лом 6 сейн ти в меж х сільських р д відповідних р йонів з зн є середнього нтропогенного втруч ння. 
икон ні дослідження 3 свідчили, що н екологічний ст н б сейну річки т , окрім урбосистем міст ервоногр д, ок ль, овкв, смт ірник, м. еликі ости, смт герів, зн чно вплив ють: ступінь $з$ ліснення, сільськогоспод рськ освоєність, розор ність, урб нізов ність території. Г лом стійкість л ндш фтів території досліджень нест більн . пок зник ми нтропогенної тр нсформ ції геосистем з'ясов но, що екологічний ризик у меж х б сейнової системи ти є середнім; екологічне н пруження в 6 сейні р. т нез довільне (т бл. 5).

блиця 5

нтропогенне н в нт ження в б сейні р. т

\begin{tabular}{|c|c|c|}
\hline ок зники & н чення & ритерій \\
\hline & 0,98 & ест більний \\
\hline стк нтропогенних геосистем & 0,48 & - \\
\hline тупінь природного вигляду території & $30 \%$ & ез довільний \\
\hline оефіцієнт нтропогенної тр нсформ ції території & $64 \%$ & - \\
\hline оефіцієнт стійкості грол ндш фтів & 1,6 & - \\
\hline оефіцієнт екологічної зб л нсов ності території & 1,50 & - \\
\hline кологічний ризик & 5,41 & ередній \\
\hline ісистість & $29 \%$ & обрий \\
\hline ільськогоспод рськ освоєність території & $61 \%$ & обрий \\
\hline озор ність & $40 \%$ & обрий \\
\hline $\begin{array}{l}\text { стк сінож тей і п совищ у структурі сільського- } \\
\text { спод рських угідь }\end{array}$ & $20 \%$ & - \\
\hline рб нізов ність, \% & $3 \%$ & орм льний \\
\hline
\end{tabular}

ля зменшення нтропогенного н в нт ження н річково-б сейнову систему ти необхідно вжити комплекс оптиміз ційних орг ніз ційно-господ рських, орг ніз ційно-технічних, технічних, гідро гротехнічних і лісомеліор тивних з ходів, спрямов них н збереження цілісності й комплексного підходу до використ ння природних ресурсів тр нскордонного регіону.

о основних 3 ходів оптиміз ції функціонув ння річкового 6 сейну н леж ть структуриз ція сільськогоспод рських угідь, лісорозведення т лісовідновлення, дотрим ння пр вил водоохорони в меж х прибережних 3 хисних смуг, екологічне вихов ння, т кож удоскон лення системи моніторингу довкілля тощо.

1. родзинський . . снови л ндш фтної екології : підручник / . . родзинський. - . : ибідь, 1993. - 224 с.

2. лименко . . кологічний ст н укр їнської ч стини врорегіону “уг” / . . лименко, . . ознюк. - івне : ,2007. - 203 с.

3. ург невич. . сейновий підхід до оцінки впливу землекористув ння н ст н н вколишнього середовищ / . . ург невич // ук. вісник ціон. ун-ту біоресурсів і природокористув ння. - 2009. - ип. 118. - . 56-62.

4. ург невич . . изн чення екологічної стійкості геокомплексів 6 сейну річки олтви / . . ург невич, . . іпк // ук. 3 п. . ер. геогр. - 2012. № 2. - .94-101. 
5. ург невич . ідрологічний н ліз б сейнової системи олокії / . ург невич, . нилевич // т н, проблеми і перспективи природничої геогр фії : м тері ли круглого столу. - ьвів : імені в н р нК , 2011.- .138-143.

6. ург невич . . колого-геогр фічний н ліз річкового 6 сейну ти / . . ург невич // ук. 3 п. ер. геогр. - 2006. - № 2. - . 199-206.

7. ург невич . етодичні підходи до н лізу екологічного ст ну річкового б сейну олтви / . ург невич, . іпк // еогр фічні з с ди вирішення регіон льних проблем : м тері ли іжн р. н ук.-пр кт. конф. - м'янець- одільський : водейко, 2010. - . 124-126.

8. ург невич . . мови формув ння т Ф ктори впливу н водний режим річки олтв / . . ург невич, . . іпк // існик ьвів. ун-ту. ер. геогр. - 2012. ип. 40, ч. 2. - . 52-59.

9. етодичне керівництво по розр хунку нтропогенного н в нт ження і кл сифік ції екологічного ст ну 6 сейнів м лих річок кр їни. - . : , 1992. - 40 с.

10. ретяк . . етодологія т методик н укових досліджень у землевпорядкув нні : н вч. посібник / . . ретяк, . . утч к. - . : гр рн н ук , 2005. - 300 с.

11. оновий моніторинг н вколишнього середовищ / [3 ред. . . риходьк ]. в но- р нківськ : олі нт, 2010. - 322 c.

12. http://oblwodgosp.lviv.ua/richki.

13. http://www.zbbuvr.gov.ua/Monitoring/Results.html.

m ття: н дійшл до ред кцї 03.04.2014

доопр иьов н 05.05 .2014

прийнят до друку 15.10.2014

\section{EVALUATION OF HUMAN PRESSURE ON THE RATA RIVER-BASIN SYSTEM}

\section{Liudmyla Kurhanevych, Lilianna Verbenets}

Ivan Franko National University of Lviv, P. Doroshenko Str., 41, UA - 79000 Lviv, Ukraine

The urgency of geo-environmental research of river systems status through the analysis of anthropogenic load on their pools has been substantiated. The main approaches to the assessment of anthropogenic impact on the river basin system and the structure of land use have been analyzed, the degree of environmental sustainability of landscapes, ecological balance area environmental sustainability of land use, and environmental stress within the Rata basin have been assessed.

Key words: river-basin system, human pressure, land use and environmental sustainability. 